\title{
Getting back to fire sumés: exploring a multi-disciplinary approach to incorporating traditional knowledge into fuels treatments
}

Monique D. Wynecoop ${ }^{1 *}$, Penelope Morgan², Eva K. Strand ${ }^{2}$ and Fernando Sanchez Trigueros ${ }^{3}$

\begin{abstract}
Background: Evaluating fuel treatment effectiveness is challenging when managing a landscape for diverse ecological, social, and economic values. We used a Participatory Geographic Information System (PGIS) to understand Confederated Colville Tribal (CCT) member views regarding the location and effectiveness of fuel treatments within their ancestral territory within the Colville National Forest (CNF) boundary. The 2015 North Star Fire burned 88221 ha (218 000 acres) of the CCT ancestral territory.

Results: We sampled thirty plot pairs that were treated or untreated prior to being burned by the North Star Fire and again one growing season post fire. Species diversity was significantly increased by wildfire in both treated and untreated plots. Species richness was significantly increased in the plots that were treated, and there was no significant change in species richness from wildfire within the untreated plots. The percent canopy cover of two of the six culturally important plants (Fragaria spp. L. and Arnica cordifolia Hook.) significantly increased one growing season post wildfire within treated plots and one (Arctostaphylos uva-ursi [L.] Spreng.) significantly decreased in the treated plots post wildfire. These post-fire monitoring results were consistent with CCT member management recommendations and desired outcomes of understory thinning, prescribed fire, and natural ignition found using PGIS.
\end{abstract}

Conclusions: Together, the results suggest that prior thinning and prescribed burning can foster vegetation response to subsequent wildfires, including culturally important plants. Further, integrating Traditional Knowledge (TK) into fuels treatments can improve ongoing adaptive management of national forests that include tribal ancestral lands.

Keywords: fire effects, fuel treatment effectiveness, northeastern Washington, participatory geographic information systems, social ecological systems, Traditional Knowledge

\footnotetext{
* Correspondence: moniquedwynecoop@fs.fed.us

${ }^{1}$ USDA Forest Service, Colville National Forest, 765 S. Main Street, Colville,

Washington 99114, USA

Full list of author information is available at the end of the article
} 


\section{Resumen}

Antecedentes: La evaluación sobre la efectividad de los tratamientos de combustibles, implica un desafío cuando se gestiona un paisaje para lograr diversos objetivos, incluyendo valores sociales, económicos, y culturales. Usamos el Sistema de Información Geográfica Participativo (PGIS) para entender los puntos de vista de los miembros de la Confederación Tribal de Colville (CCT), en relación a la ubicación y efectividad de tratamientos de raleo, quemas prescriptas e incendios en su territorio ancestral dentro de los límites del Bosque Nacional de Colville (CNF). El incendio Ilamado North Star Fire de 2015 quemó 88000 ha (218 000 acres) del territorio ancestral CCT.

Resultados: Treinta parcelas apareadas que habían sido tratadas y no tratadas fueron muestreadas antes de ser quemadas por el incendio North Star y nuevamente muestreadas en la siguiente estación de crecimiento. La diversidad de especies se incrementó significativamente por el fuego en ambos tratamientos (tratados y no tratados). La riqueza de especies se incrementó significativamente en las parcelas tratadas, y no hubo cambios significativos debido al fuego dentro de las parcelas no tratadas El porcentaje de cobertura del dosel de dos de las seis plantas culturalmente importantes (Fragaria spp. L. y Arnica cordifolia Hook.), se incrementó significativamente en la estación siguiente al incendio dentro de las parcelas tratadas y una, (Arctostaphylos uva-ursi [L.] Spreng.), decreció significativamente en las parcelas tratadas en el período post fuego. Estos resultados del monitoreo post-fuego fueron consistentes con las recomendaciones de manejo de los miembros del CCT y de los logros deseables del raleo del sotobosque, de las quemas prescriptas y las igniciones naturales usando el sistema de información participativo (PGIS).

Conclusions: De manera conjunta, los resultados sugieren que el raleo previo y las quemas prescriptas pueden promover la respuesta de la vegetación a incendios subsecuentes incluyendo plantas culturalmente importantes. Además, la integración del conocimiento tradicional (TK) en el manejo de combustibles, puede mejorar el manejo adaptativo en los bosques nacionales que incluyen tierras tribales ancestrales.

\section{Introduction}

The Confederated Colville Tribes (CCT), Spokane Tribe, and Kalispel Tribe all have ancestral lands surrounding and within the Colville National Forest (CNF) boundary. These tribes have unique dialects, yet share similarities and are part of the Interior Salish linguistic family, which encompasses languages spoken by tribes from the Columbia River, as far east as Montana,USA, and north into British Columbia, Canada (Curtis 2010). Sumés (pronounced "Su-mesh") is an Interior Salish word used to describe spirit power. Traditionally, those who manage fire hold a great responsibility because they have the sumés to manage the landscape that sustains and provides for their tribe (Boyd 1999). The Spokane and Confederated Colville tribes of northeastern Washington, USA, have long valued fire as medicine for the land, which is why the role of fire managers was historically an honor held by medicine men and women within the tribe. Although much has changed since the establishment of reservation borders and the removal of the CCT and fire from their ancestral territories in the late 1800s, the culture remains for the tribal people. The social and ecological complexity of modern landscapes requires that fire managers and scientists develop approaches towards fuels treatments and wildland fire management that allow for stakeholder input while also maintaining trust and protecting the confidentiality of local knowledge (Gunderson et al. 2011). Since 1907, the Colville National Forest of northeastern Washington has been managing natural resources within the ancestral territories of the Spokane, Kalispell, and CCT. Traditional Knowledge (TK) is best described by the Spokane Tribe as sustainable living that is, "rooted in a larger more umbrella-like-social decision making structure that tribes have relied upon for millennia" and strives to follow "traditional ecological theory and philosophy passed down by our elders" (STOI [Spokane Tribe of Indians] 2012). Berkes et al.. (2000) further describe TK as a "cumulative body of knowledge, practice, and belief, evolving by adaptive processes and handed down through generations by cultural transmission, about the relationship of living beings (including humans) with one another and their environment." For countless prior generations, these tribes have used TK to manage their traditional hunting, gathering, and prayer sites with locally adapted fuels reduction and fire ecology techniques. Such techniques have perpetuated the use of those locations and increased the resilience and resistance of those areas to large fire events. Many forests of the western United States that were thought to be shaped by wildfire have been found to be influenced more by intentional burning by indigenous people (Kimmerer and Lake 2001).

TK of the local tribes has not been routinely incorporated into fuels treatments on the CNF. TK could potentially enhance efforts to reduce hazardous fuels while also addressing local tribal and non-tribal natural resource needs by identifying the most suitable techniques, locations, and conditions under which to implement prescribed burns and other fuels treatments. However, 
protecting and maintaining the confidentiality and trust of tribes is a barrier to integrating TK into management.

The CCT is composed of descendants from twelve tribes and their bands, including the Colville, Nespelem, Sanpoil, Lake, Palus, Wenatchi, Chelan, Entiat, Methow, southern Okanogan, Moses Columbia, and Nez Perce of Chief Joseph's bands. Many of the local tribes of northeastern Washington were confined to a 1200000 ha reservation in 1872, now known as the Colville Reservation. Soon after, another executive order by President Grant reduced the reservation by half to 567000 ha, without any consultation with the tribes impacted (CCT 2017). In 1892, the northern half of the reservation that was originally part of the Confederated Colville Tribes' 1872 reservation boundary was ceded to the United States by an act of Congress (Fig. 1). The "North Half," as it is called by the $\mathrm{CCT}$, is known by the non-native community as the western CNF landscape, which lies west of the Columbia River and east of the Kettle Crest, Washington. Through treaties with the US government, leaders of the Colville tribes reserved their rights to hunt, fish,

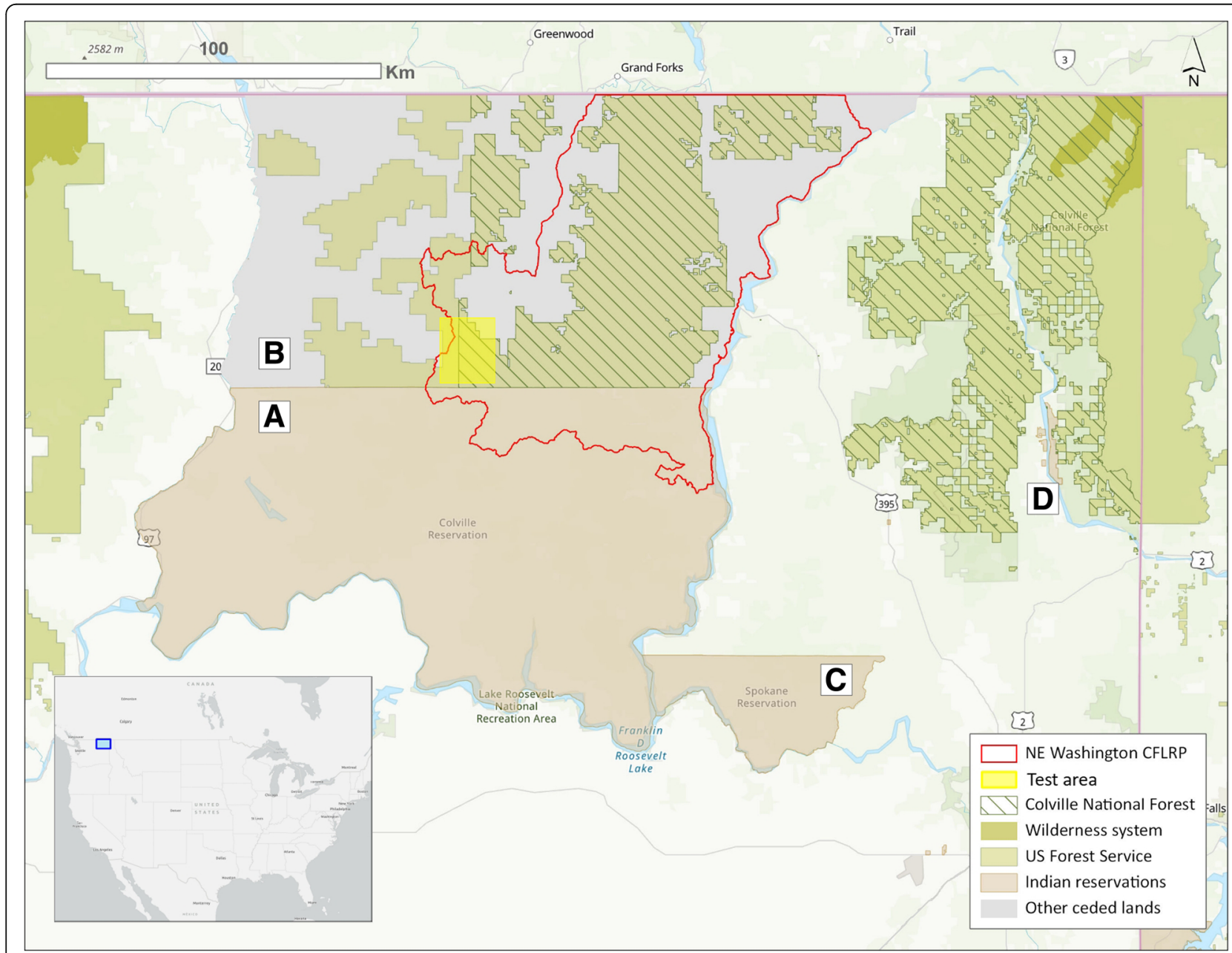

Fig. 1 Study area and jurisdictional context. The ancestral territories of the Colville Confederated Tribes expand far beyond what is now known as the Colville Reservation, through Washington, Oregon, and Idaho, USA, and British Columbia, Canada (CCT 2017). The Colville Reservation was established by Executive Orders of 9 April and 2 July 1872 to originally encompass the lands between the Okanogan and Columbia rivers and the USA-Canada border ( $\mathbf{a}$ and $\mathbf{b}$ ). The Spokane and Kalispel tribes were not designated to live on the Colville Reservation, though. The Spokane Reservation was established by Executive Order of 18 January 1881 (c) and the Kalispel Reservation was established more than three decades later by Executive Order of 23 March 1914 (d). On 1 July 1892, an act of Congress executed the cession of all the Colville Reservation lands from Township 35 (48 $\left.28^{\prime} 56^{\prime \prime} \mathrm{N}\right)$ to the Canadian border for allotment or sale (b). On 1 March 1907, most of the ceded north half from Range 33 $\left(118^{\circ} 52^{\prime} 12^{\prime \prime} \mathrm{W}\right)$ to the Columbia River was declared the Colville Forest Preserve by presidential proclamation of Theodore Roosevelt, which is currently included in the Colville National Forest. Red outline: this study focused on the Old North Half now administered by the Colville National Forest, and a portion of the present-day Colville Reservation. Additionally, vegetation was sampled on 30 paired plots within the test area (highlighted in yellow), which covers part of the area burned by the 2015 North Star fire within the Northeastern Washington Collaborative Forest Landscape Restoration Area (CFLRP) project boundary. Base maps provided by ESRI (2014) 
and gather within the North Half in perpetuity (CCT 2017).

Ecosystem processes such as fire are complex and span beyond jurisdictional boundaries. The traditional lifestyle of the CCT historically extended far beyond what is now the reservation boundary to various hunting, fishing, trading, and praying sites (Fig. 1). In order to perpetuate cultural knowledge and traditional lifestyles for future generations, tribes such as the CCT are striving for improved access and co-management of their ancestral homelands outside the reservation.

In the face of landscape-scale disturbances such as fire, as well as global changes such as land-use conversion and climate change, indigenous people around the world are becoming more determined to protect and reassert their right to co-manage valued resources outside their current jurisdictional boundaries (Green and Raygorodetsky 2010; Voggesser et al. 2013). Other local people who live in the communities that border the CNF have economies that are heavily influenced by fire and its influence on hunting, logging, recreation, and commercial and private mushroom and berry harvest.

Multi-jurisdictional management of fire-prone landscapes is increasingly important, given the risk of large fires, fuel treatments, or other management practices that affect the abundance of plants and other culturally significant resources (DellaSala et al. 2003; Agee and Skinner 2005; Swanson and Gilgert 2009). Local research is needed for communities and agencies to adapt fuels reduction strategies to regional and climate-driven complexities and to restore the integrity of forests (Hessburg et al. 2015). In order to protect ecosystems and traditional lifestyles in the wake of large wildfires, there needs to be a certain level of trust and strong communication among scientists, managers, and local communities so that forestry and fuels prescriptions are not only scientifically sound but also culturally relevant to the local communities (Lake et al. 2017).

Cultural values must be part of evaluating fuel treatment effectiveness. While many studies have evaluated fuel treatment effectiveness in terms of fire behavior and fire suppression (e.g., Hudak et al. 2011; Fulé et al. 2012), and many others have evaluated how plants respond to fuels treatments (e.g., Metlen et al. 2004; Gundale et al. 2005; Kane et al. 2010; Kalies and Yocom Kent 2016; Willms et al. 2017), few have evaluated how fuel treatments alter plant response to wildfire. Even fewer studies have investigated how wildfire is managed in indigenous communities (Carrol et al. 2010; Christiansen 2015) or have incorporated TK regarding cultural plants and other tribal uses of ancestral lands and the effects of fire on those uses (Kimmerer and Lake 2001). Fire and fuels management that integrates TK with other social values will potentially be more sustainable within forests that have long been adapted to human-ignited fires.

Our objectives were to: 1) investigate how prior fuel treatments influenced understory vegetation response to the North Star Fire-we focused both on overall species diversity and the abundance of six individual culturally important plants; 2) determine how tribal participants perceived the effects of fuel treatments on cultural practices such as hunting, fishing, and gathering; and 3) evaluate where tribal participants felt that CNF fuel treatments should be done or be avoided based upon their expected influence on tribal cultural values. Our overall goal was to foster tribal input and improve collaboration between CCT and CNF to better natural resources management on the CNF.

\section{Methods}

\section{Study area}

This research took place on the western side of the Colville National Forest within the Northeastern Washington (NEW) Forest Vision 2020 Collaborative Forest Landscape Restoration Project (CFLRP) area (Fig. 1). The mixed conifer forests of the North Half are dominated by lodgepole pine (Pinus contorta Douglas ex Loudon), Douglas-fir (Pseudotsuga menziesii [Mirb.] Franco) and grand fir (Abies grandis [Douglas ex D. Don] Lindl.) (USDA Forest Service 2014). The elevation ranges from 487 to $1826 \mathrm{~m}$ (USDA Forest Service 2014). Prior to the designation of the CCT Reservation boundary in 1887, light surface fires were common, with fires at 0- to 35-year intervals in dry mixed-conifer sites, and 35- to 100-year intervals for moist sites such as wetlands, meadows, aspen stands, and riparian areas, as estimated by Stine et al. (2014). Fire suppression and limits on human-ignited fires have since led to dense, thick stands that are susceptible to disease and infestation and are more prone to crown fire (Stine et al. 2014; Hessburg et al. 2016). In the absence of fire history studies here, we assumed that fire regime reconstructions summarized by Stine et al. (2014) for other dry mixed conifer forests apply to these CNF forests.

\section{Vegetation response to wildfire with or without prior fuel treatments}

We contrasted understory vegetation response to wildfire within areas that underwent prior mechanical thinning and prescribed burning within the previous 10 years, with areas that received no treatment within the previous 10 years. The plots were randomly located within past United States Forest Service (USFS) fuels treatments that were within the boundary of the North Star Fire. This wildfire started around 13 August 2015, about $40 \mathrm{~km}$ north of the Grand Coulee Dam, 
Washington. The North Star Fire burned more than 88277 ha, 7284 ha of which occurred on the CNF.

We collected data from 15 paired plots that were treated (mechanically thinned and prescribed burned to reduce fuels and therefore fire hazard) or untreated. Treatment categories were defined as $\mathrm{T}$ (treated by pre-commercial thinning and prescribed burning), TB (treated by pre-commercial thinning and prescribed burning and then burned by the 2015 wildfire), and B (untreated-not recently thinned or prescribed burned in the past decade and burned by the 2015 wildfire). Treated units were pre-commercially thinned in 2007 and then prescribed burned a year post treatment. Ten of our $\mathrm{T}$ and $\mathrm{TB}$ plot pairs were sampled within areas that were pre-commercially thinned and prescribed burned prior to being re-burned by the wildfire $(\mathrm{T})$ in early September 2015 (while the fire was still burning) using a rapid response protocol and wildfire safety standards similar to those outlined by Lentile et al. (2007); thus, plots had to be visible from the road. We sampled the exact plot locations post wildfire (TB) in May 2016. In addition, five pairs of TB and B plots were sampled in May 2016 with each pair established in treated and untreated areas that were otherwise similar with respect to aspect, elevation, slope, slope position, and all in mixed-conifer forest. All plots were on land managed by the CNF within the boundary of the North Star Fire. All pairs had similar slope (15 to $25 \%$ ) and south-facing aspect, with elevation from 1125 to $1292 \mathrm{~m}$ ). All plots were randomly located and they had to be at least $50 \mathrm{~m}$ from any skid trails, roads, or landings. Plot centers were permanently marked with rebar and all data are on file on the Colville National Forest as forest monitoring data.

We adapted the fire effectiveness monitoring framework and Before After Control Impact (BACI) design that was already being used as a part of the NEW Vision 2020 monitoring program. We used FIREMON methods (Lutes et al. 2006), including the Plot Description (PD), Tree Data (TD), Species Composition (SC), and Microplot Photoload and Fuel Data Forms (Wynecoop 2017). On each plot, the understory plant information (species, ocular estimate of percent canopy cover of each species, and height), ground cover (ocular estimate of percent cover, bare soil, rock, wood, charred ground, gravel, litter and duff, moss and lichen, and ash) were collected within five $2 \mathrm{~m} \times 2 \mathrm{~m}\left(4 \mathrm{~m}^{2}\right)$ microplots. Ground cover and tree data (diameter at breast height $[\mathrm{DBH}]$, and total height) were also collected within a $11.3 \mathrm{~m}$ diameter plot around the plot center.

\section{Vegetation analysis}

We included the understory vascular plant species that were found in at least three of the 30 total plots for calculation of total species richness and diversity. The common and scientific names were taken from the USDA Plants database (USDA NRCS 2017; Additional file 1).

Data were first tested for adequate sample size (number of plots) using a species-area curve within the PC-ORD software program (McCune et al. 2002). Differences in species richness and Shannon-Wiener Diversity Index (Shannon 1948) were evaluated for paired plots with a blocked multi-response permutation procedure (MRBP) with a Euclidean distance measure in PC-ORD, with treatment type being the grouping variable and pair being the blocking variable. MRBP does not require assumption of normal distribution of variables (McCune et al. 2002). Species richness, Shannon-Wiener Diversity Index, and individual species abundance data were compared by treatment $A$ - and $P$-values. The $A$ statistic is a measure of agreement between groups, where $A=1$ for complete within-group homogeneity; $A=0$ when the heterogeneity within groups is equal to the expectation; and $A<0$ if there is less agreement within groups than expected by chance (McCune et al. 2002). The $P$-value represents the probability that there is no difference between groups. In all analyses, we used $P<0.1$ to determine statistical significance.

In order to demonstrate how managers can address specific questions regarding cultural plants, we analyzed the percent canopy cover of six individual plant species chosen based on their commonly known edible or medicinal uses (Kershaw 2000). For each of those six culturally important plant species, the percent canopy cover was compared for plot pairs using MRBP with a Euclidean distance measure in PC-ORD.

\section{Assessing cultural values about fuels treatment effects and locations}

Participatory GIS (PGIS) exercises have helped collaborative landscape management efforts of the Confederated Salish and Kootenai tribes of the Flathead Reservation, Jemez Pueblo, and the Santa Clara Pueblo (McBride et al. 2017). The combination of involving a trusted tribal representative in the project from the very beginning, along with the user-friendly technology and confidentiality of the PGIS programs such as Mapping Meanings, allows tribal input that might otherwise go unshared. Here, the PGIS exercise and the fuels monitoring plots were funded by and incorporated into the CNF (2011) CFLRP as socioeconomic monitoring that will help address how USFS fuels treatments are impacting tribal values.

We used Map-Me to solicit feedback from CCT participants during the fall of 2015. Map-Me (http://mapme.org) is an online public PGIS program designed to collect participatory mapping and comments. It is a user-friendly computer-based geospatial interface combined with a spray-can tool that allows users to map 
values and concerns on a landscape in a "fuzzy" way, so that the specific location of those values aren't given. Due to the program's ability to protect sensitive information, confidentiality of participants, and tribal ownership of the data, we solicited the help of the Rocky Mountain Research Station and their Map-Me PGIS program to help the USFS and the CCT collaboratively address concerns regarding USFS management practices and their locations within the North Half. The Confederated Colville Tribes own the information collected from the Map-Me exercise and any request to use the information needs to go through an approval process with the CCT. Without such a safeguard of the CCT's sensitive information, this project could not exist. Through the Map-Me program, tribal participants voiced their views regarding three categories of Forest Service fuels treatments (mechanical thinning, prescribed burning, and wildfire) within the North Half of the original Colville Reservation.

We used our PGIS exercise to determine the impacts of the commonly practiced fuels treatments on the cultural practices of the Confederated Tribes of the Colville Reservation. We used the cultural practices listed in the CCT's recent Integrated Resource Management Plan (CCT 2015), including hunting, fishing, gathering of plants and other natural resources, gathering of firewood, and the use of off-road vehicles for participating in their cultural practices. We also used PGIS to map where participants felt that fuels treatments should be applied or not, and how (if at all) they feel the methods should be modified.

The three types of fuels treatments we discussed in the PGIS exercise were: 1) non-commercial mechanical thinning, including thinning of the understory by mastication (i.e., mechanical chipping) of vegetation; 2) prescribed fire, in which fire is applied to the landscape under specific weather and fuel conditions to accomplish specific management objectives such as fuels reduction; and 3) managing naturally occurring wildfires for resource benefit.

The Map-Me PGIS exercise consisted of a demographic questionnaire (Additional files 2, 3, 4 and 5), followed by a fuels treatment questionnaire, and then a mapping exercise that allowed the participant to explain feelings or concerns related to what they put on the map (Wynecoop 2017). The questionnaire allowed participants to describe in detail how each treatment type impacts each of their cultural uses of the North Half. The mapping exercise allowed the participants to map where they think each method of treatment should and should not be placed within the North Half.

\section{Participants}

The tribal participants included employees of the Colville Tribe and the Bureau of Indian Affairs (BIA), as well as CCT tribal members and descendants. We targeted a diverse representation from different management or senior roles in cultural and natural resources management of the CCT and the BIA. Most of the participants were employees from the BIA or CCT that worked in natural resources programs such as Forestry, Fish, Wildlife, Parks and Recreation, Environmental Trust, Mount Tolman Fire Control Station, Law Enforcement Office, and the Culture and History Department (Additional file 5). We were able to meet with participants at the BIA or Tribal offices or at the tribal community centers and assist them with technical issues and questions. There was no time or word limit for typed responses and, depending on how much someone wanted to write, the entire PGIS exercise took anywhere from $30 \mathrm{~min}$ to $3 \mathrm{~h}$. We had 40 participants agree to take part in the scoping group during our visit from 30 November to 3 December 2015. Of those 40 participants, 37 completed the exercise (Additional file 6).

\section{Data sources}

GIS data of fuel treatment locations and types that have been accomplished and maps of project area and wildfire perimeters were obtained from the USFS CNF GIS database.

\section{PGIS analysis}

In order to facilitate the incorporation of TK into USFS fuels treatments, we produced the final tessellated maps of locations where the CCT participants would like to see more fuels treatments and where fuels treatments should be avoided. To accomplish this, we conducted a geospatial analysis of the pilot study data and responses using the software GRASS GIS (https://grass.osgeo.org/) and ad hoc scripting in R (Ihaka and Gentleman 1996), Python (https://www.python.org/), and Unix shell coding. The heat maps and comments provided by participants were then used to assess whether fuels treatments have been meeting $\mathrm{CCT}$ needs. In the future, the maps will be used by the CCT and CNF to make comparisons to current planned projects and to help make recommendations on how to tailor future fuels treatments and wildfires within the North Half to address identified CCT needs and concerns.

The PGIS comments were organized into perceived impacts of treatments on gathering of cultural plants, management recommendations, and desired outcome using data-driven coding techniques outlined by Boyatzis (1998) and DeCuir-Gunby et al. (2011), and then organized in a table (Table 1). A qualitative content analysis was used to graph the information based on how often each theme was mentioned and how often management recommendations were mentioned. 
Table 1 Common themes for management addressed by PGIS participants $(n=37)$ were organized into perceived impacts on gathering of cultural plants and materials, management recommendations, and desired outcome of mechanical thinning, prescribed fire, and wildfire. NA = those comments that included a perceived impact and desired outcome but not a management suggestion. Depends $=$ the impact depends on whether or not the desired outcome is met

\begin{tabular}{|c|c|c|}
\hline Perceived impact & Management suggestion & Desired outcome \\
\hline \multicolumn{3}{|c|}{ Mechanical thinning } \\
\hline Beneficial & More treatments & Native plants benefit \\
\hline Beneficial & NA & Reduce stand-replacing fire \\
\hline Beneficial & NA & Reduce smoke \\
\hline Beneficial & More treatments & Huckleberry plants become healthier \\
\hline Beneficial & More treatments & Access improves for public and tribal members \\
\hline Beneficial & More treatments & Access improves for public and tribal members \\
\hline Beneficial & More treatments & Cedar roots straighter and better quality for basketry \\
\hline Beneficial & More treatments & Huckleberry berries grow larger \\
\hline Beneficial & More treatments & Thin understory vegetation \\
\hline Beneficial & More treatments & Access improves for public and tribal members \\
\hline Beneficial & NA & Access improves for public and tribal members \\
\hline Beneficial & More treatments & Native plants benefit \\
\hline Beneficial & More treatments & Thinned understory vegetation more productive \\
\hline Beneficial & More treatments & Thinned understory vegetation more productive \\
\hline Beneficial & More treatments & Native plants benefit \\
\hline Damaging & NA & Assess short-term damage from operations \\
\hline Damaging & Less roads & Huckleberries not overpicked or overbrowsed \\
\hline Damaging & Less roads and log decking & Avoid damaging medicinal foods \\
\hline Damaging & Less roads & Reduce heavy metals in edible and medicinal plants \\
\hline Damaging & Less treatments & Understory vegetation grows bigger and better \\
\hline Damaging & Less treatments & Damaged native plants need shade and water to recover \\
\hline Damaging & Less treatments & Avoid damage to native plants so they return \\
\hline Damaging & Natural fire is best & Forest ecology and cultural plants benefit most from natural fire \\
\hline Damaging & Reduce commercial tree selection & Prioritize tree-take based on forest need, not money \\
\hline Depends & NA & Management practice depends on species focus \\
\hline Depends & NA & Management practice depends on species focus \\
\hline Depends & NA & Short-term damage for long-term benefits \\
\hline Depends & Combine with fire & Fire-adapted traditional plants benefit \\
\hline Depends & Combine with fire & Stimulate traditional plant growth \\
\hline Depends & Remove slash & Avoid excessive ignitions due to slash accumulation \\
\hline Depends & Remove slash & Improve access to food, medicines, and firewood \\
\hline \multicolumn{3}{|l|}{ Prescribed burning } \\
\hline Beneficial & More treatments & Improve access for elders \\
\hline Beneficial & More treatments & Fire-adapted traditional plants flourish \\
\hline Beneficial & More treatments & Improves wildlife corridors \\
\hline Beneficial & More treatments & Improves cultural plants \\
\hline Beneficial & More treatments & Healthier medicinal plant communities \\
\hline Beneficial & More treatments & Improve access \\
\hline Beneficial & More treatments & Rejuvenates plants and nutrients in plants \\
\hline Beneficial & More treatments & Reproduces new growth and increases nutrients in plants \\
\hline Beneficial & More treatments & Increase mushroom gathering opportunities \\
\hline
\end{tabular}


Table 1 Common themes for management addressed by PGIS participants $(n=37)$ were organized into perceived impacts on gathering of cultural plants and materials, management recommendations, and desired outcome of mechanical thinning, prescribed fire, and wildfire. NA = those comments that included a perceived impact and desired outcome but not a management suggestion. Depends = the impact depends on whether or not the desired outcome is met (Continued)

\begin{tabular}{|c|c|c|}
\hline Perceived impact & Management suggestion & Desired outcome \\
\hline Beneficial & More treatments & Huckleberry berries grow larger \\
\hline Beneficial & More treatments & Huckleberry plants become healthier \\
\hline Beneficial & More treatments & Fire-adapted plants benefit \\
\hline Beneficial & More treatments & Fire-adapted plants benefit \\
\hline Beneficial & More treatments & Allows native plants to regenerate and eliminate competition \\
\hline Beneficial & More treatments & Burned understory vegetation healthier and more productive \\
\hline Beneficial & More treatments & Improves overall forest health \\
\hline Beneficial & More treatments & Reduce stand-replacing fire \\
\hline Beneficial & More treatments & Healthier medicinal plant communities and ecosystem \\
\hline Damaging & Less treatments & Prevent disturbing the cultural plants too much \\
\hline Depends & NA & Work with tribe to protect sensitive cultural spots \\
\hline Depends & Mimic natural variability & Produce natural patchiness \\
\hline Depends & Depends on timing & Time around when most beneficial to cultural plants \\
\hline Depends & NA & Improves availability of cultural plants and reduces invasive plants \\
\hline Depends & NA & Prevent favoring invasive species \\
\hline Depends & More wildfire & Not a viable investment \\
\hline Depends & Mimic natural variability & Plants need areas of lower intensity so they can re-establish \\
\hline \multicolumn{3}{|l|}{ Wildfire } \\
\hline Beneficial & Allow to burn when safe & Clears excessive overgrowth and opens up habitat for cultural plants \\
\hline Beneficial & Allow to burn when safe & Makes cultural plants stronger \\
\hline Beneficial & Allow to burn when safe & Allows cultural plant rebirth \\
\hline Beneficial & Allow to burn when safe & Clears weeds \\
\hline Beneficial & Allow to burn when safe & Bigger berries and healthier producing trees \\
\hline Beneficial & Allow to burn when safe & Makes cultural plants more available \\
\hline Beneficial & Allow to burn when safe & Improves overall forest health \\
\hline Beneficial & Allow to burn when safe & Helps clear soil of weeds \\
\hline Damaging & More treatments & Keep wildfires on the ground and out of the canopy \\
\hline Depends & Leave burned areas alone & Area recovers and wildlife return if tractors and logging equipment stays out \\
\hline Depends & Don't let fire burn too hot & Prevent damage to cultural plants \\
\hline Depends & Avoid post-fire removal of debris & Prevent damage to cultural plants \\
\hline Depends & Allow to burn when safe & Prevent spread of invasive plants from suppression tactics and equipment \\
\hline
\end{tabular}

To develop the codebook for the PGIS comments: 1) comments were summarized into theme and description of theme in an spreadsheet; 2) summarized comments were then separated into topics; and 3) common themes were then identified within the topics and arranged into perceived impact and desired outcome of treatment method in order for answers to be the most useful for resource managers. To determine the accuracy of the coding process used in this study, it was necessary to test the precision of agreement (also known as the interobserver agreement) between the reviewers involved in the coding process. This interobserver agreement is interpreted with the Cohen's kappa statistic. The interobserver agreement of the codes were tested by comparing a subset of our answers with the answers of two reviewers (a fire ecologist and a fire and social scientist) that were otherwise not involved with the interviews; we used their results to calculate the Cohen's kappa statistic. This statistic varies from -1 to 1 , where complete agreement between reviewers would equal 1 , chance agreement would equal 0 , and systematic disagreement would yield negative values (Viera and Garrett 2005; Cohen et al. 2013). The codes 
were also reviewed by the authors of this paper to ensure that the codes developed would be culturally sensitive to the PGIS participants, were consistent with topics discussed, and were applicable to common terms used in fire ecology and social science fields.

Comparisons were made between perceived impact and desired outcomes identified within PGIS responses and what was found through analysis of the vegetation data to help determine treatment effectiveness. These comparisons are descriptive and qualitative.

\section{Results}

Fire effects, vegetation, and fuels response

The wildfire significantly reduced $1-\mathrm{h}, 10-\mathrm{h}$, and $100-\mathrm{h}$ timelag fuels within T and TB (1-h $P=0.012,10-\mathrm{h} P=$ 0.004 , and 100-h $P=0.006$ ), as well as within TB and $\mathrm{B}$ plots (1-h $P=0.021,10$-h $P=0.026$, and 100-h $P=0.238$ ) (Fig. 2). The error bars suggest more variability in $\mathrm{T}$ than in TB plots, and also within TB than in B plots.
We observed significantly greater plant species richness within $\mathrm{TB}$ plots than within the T plots $(P=0.004$; Fig. 3). In contrast, species richness was not significantly different for TB plots compared to the B plots $(P=$ 0.850). We observed significantly higher understory plant species diversity within $\mathrm{TB}$ plots than within $\mathrm{T}$ plots $(P=0.002)$ and also within $\mathrm{B}$ plots than within TB plots $(P=0.314)$ (Fig. 3).

All six of the common edible and medicinal species re-sprouted within the established plots following wildfire. The percent canopy cover of two of the six culturally important species (Fragaria spp. L and Arnica cordifolia Hook.) significantly increased one growing season post wildfire within treated plots and one (Arctostaphylos uva-ursi [L.] Spreng.) significantly decreased in the treated plots post wildfire (Fig. 4). For huckleberry (Vaccinium myrtilloides Michx.) and Saskatoon serviceberry (Amelanchier alnifolia [Nutt.] Nutt. ex M. Roem), there was no significant difference in abundance between $\mathrm{T}$ and $\mathrm{TB}$






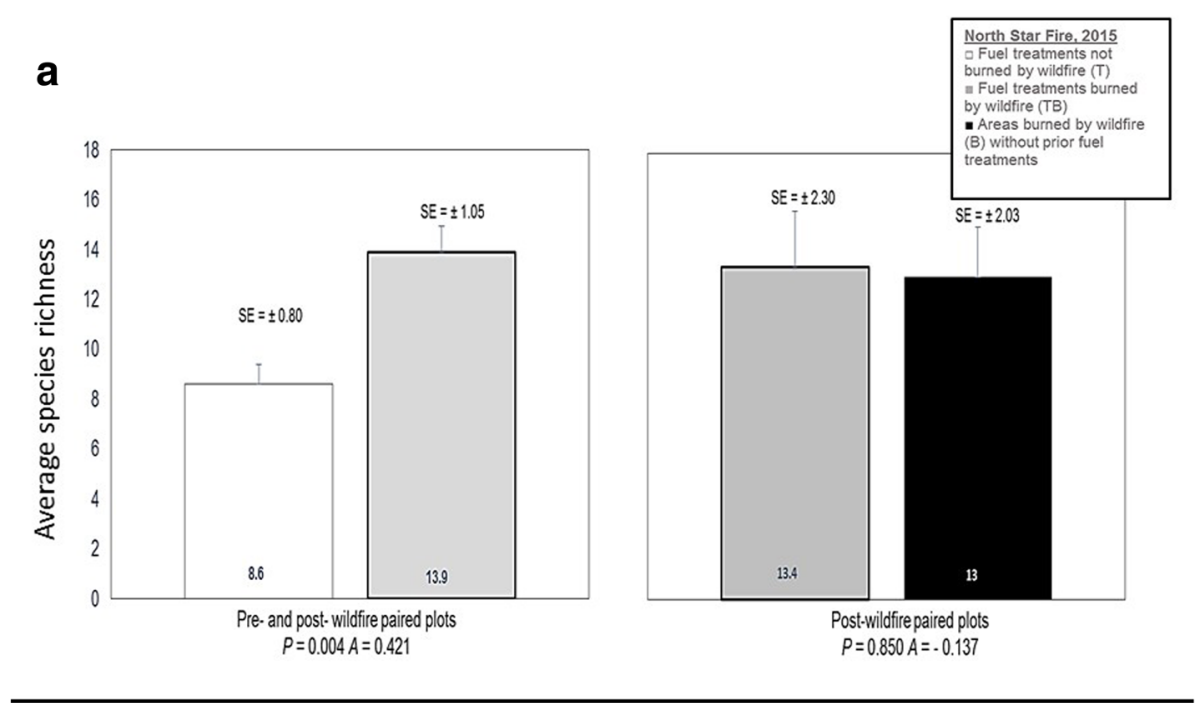

b
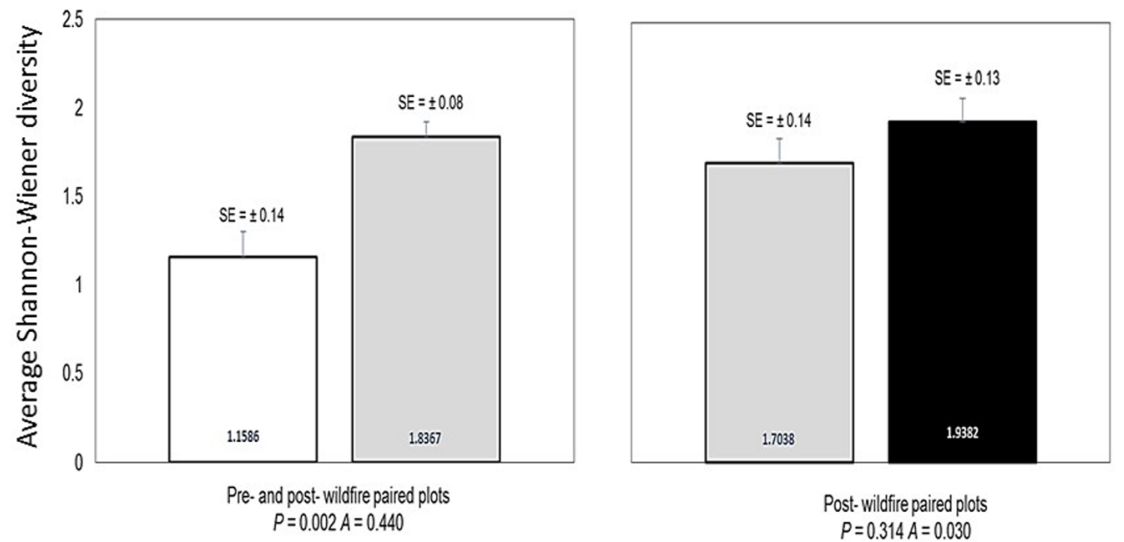

Fig. 3 Species richness (a) and Shannon-Wiener diversity (b) of 58 understory plant species on 30 paired plots. Species richness is the number of vascular plant species; the Shannon-Wiener Diversity Index is dimensionless. $P$ and $A$ values are from MRBP analysis of differences for T versus TB (ten plot pairs, a) and TB versus B (five plot pairs, b). The whiskers indicate the standard error. Data was collected within the North Star Fire perimeter September 2015 (T) and May 2016 (TB and B)

plots (huckleberry $P=0.233$, serviceberry $P=0.517$ ), nor between TB and $\mathrm{B}$ plots (huckleberry $P=0.507$, serviceberry $P=0.461$ ) (Fig. 4). With both species, variability was higher within the TB plots than within the $\mathrm{T}$ and $\mathrm{B}$ plots. For strawberry (Fragaria spp. L.), there was greater abundance within the TB plots than within the $\mathrm{T}$ plots $(P=0.006$; Fig. 4$)$, but no significant difference between TB and B plots $(P=0.809)$. For dwarf rose (Rosa gymnocarpa Nutt.), we found no significant difference in cover between T and TB plots $(P=0.764)$, nor between TB and $\mathrm{B}$ plots $(P=0.159)$ (Fig. 4). However, cover of dwarf rose was more variable within untreated plots (B plots) following wildfire without prior treatment (Fig. 4). There was lower abundance of kinnikinnick (Arctostaphylos uva-ursi [L.] Spreng.) within the $\mathrm{TB}$ plots than within the $\mathrm{T}$ plots $(P=$
0.008; Fig. 4). There was no significant difference between $\mathrm{TB}$ and $\mathrm{B}$ plots $(P=0.354)$ for kinnikinnick. Cover was less variable within all pairs following wildfire. There was higher canopy cover of heartleaf arnica (Arnica cordifolia Hook.) within the TB plots than within the T plots $(P=0.034)$, but no significant difference in canopy cover between TB and $\mathrm{B}$ plots $(P=0.769)$; however, canopy cover was more variable following wildfire (Fig. 4).

\section{Assessing cultural values about fuels treatment effects and locations}

For the two reviewers, Cohen's kappa statistic was 0.64 and 0.73 , which we interpreted as substantial agreement and high reliability of our interpretation of the PGIS qualitative comments. According to Viera 


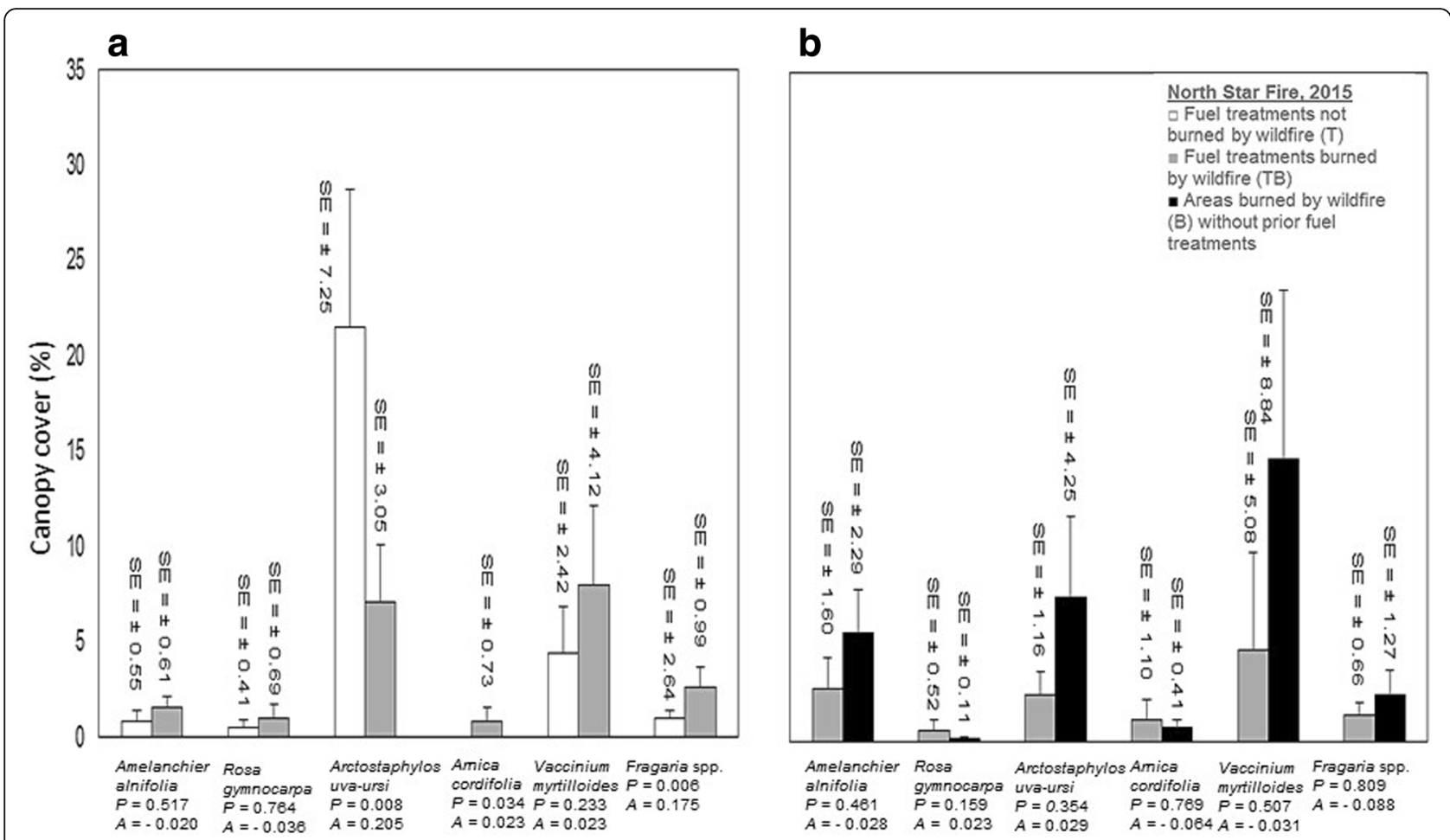

Fig. 4 Canopy cover (\%) of commonly known edible and medicinal plant species. $P$ and $A$ values are from MRBP analysis of differences for $T$ versus. TB (ten plot pairs, a) and TB versus B (five plot pairs, b). Whiskers indicate standard error. Data was collected within the North Star Fire perimeter September 2015 (T) and May 2016 (TB and B)

and Garret (2005) and Cohen et al. (2013), substantial interobserver agreement falls between 0.61 and 0.80 .

Not all of the 37 participants who completed the exercise commented on all of the questions regarding treatment type. We determined that a PGIS participant made more than one comment when they addressed more than one theme in the same answer. Regarding the effects of fuels treatments on the gathering of cultural plants and materials, there was a total of 67 comments. There were 30 comments $(n=$ 31) regarding the impacts of mechanical thinning on cultural plants. There were 21 comments $(n=19)$ regarding the impacts of prescribed burning on cultural plants. There were 16 comments $(n=18)$ regarding the impact of wildfire management on cultural plants. There was a nearly equal number of comments regarding mechanical thinning as beneficial $(n=15)$ as there were regarding it as damaging $(n=13)$ to cultural plants (Fig. 5). The comments regarding prescribed fire and wildfire were very similar, with the majority of comments viewing both wildland (beneficial $[n=8]$ vs. damaging $[n=1]$ ) and prescribed fire (beneficial $[n=18]$ vs. damaging $[n=1])$ as beneficial, with the rest of the comments showing that certain precautions or techniques needed to be used before the commenter could view the treatment type as beneficial (wildfire: depends $[n=4]$; prescribed fire: depends $[n=7])$.

The majority of comments made were in favor of more fuel treatments when the implications for culturally important plants and practices were considered (Fig. 5). The percentages reported here reflect the proportion of all comments regarding the treatment category.

1. For mechanical thinning, PGIS participants recommended that $\mathrm{CNF}$ do more treatments (39\%, $n=12)$, remove slash in a more timely manner $(6 \%, n=2)$, combine mechanical thinning with fire $(6 \%, n=2)$, make fewer roads $(10 \%, n=$ $10)$, select trees to remove based on ecological concerns rather than economic value $(3 \%, n=1)$, and natural fire is best $(3 \%, n=1)$. Many PGIS participants had no recommendation about mechanical thinning $(23 \%, n=7)$.

2. For prescribed fire, PGIS participants recommended more such treatments $(64 \%, n=18)$, that CNF personnel allow more wildfires to burn $(4 \%, n=1)$, that treatments mimic natural variability $(8 \%, n=2)$, and avoid needless treatments $(4 \%, n=1)$. Some thought that the benefit of prescribed burning depends on timing $(4 \%, n=1)$ and some had no recommendation $(11 \%, n=3)$. 


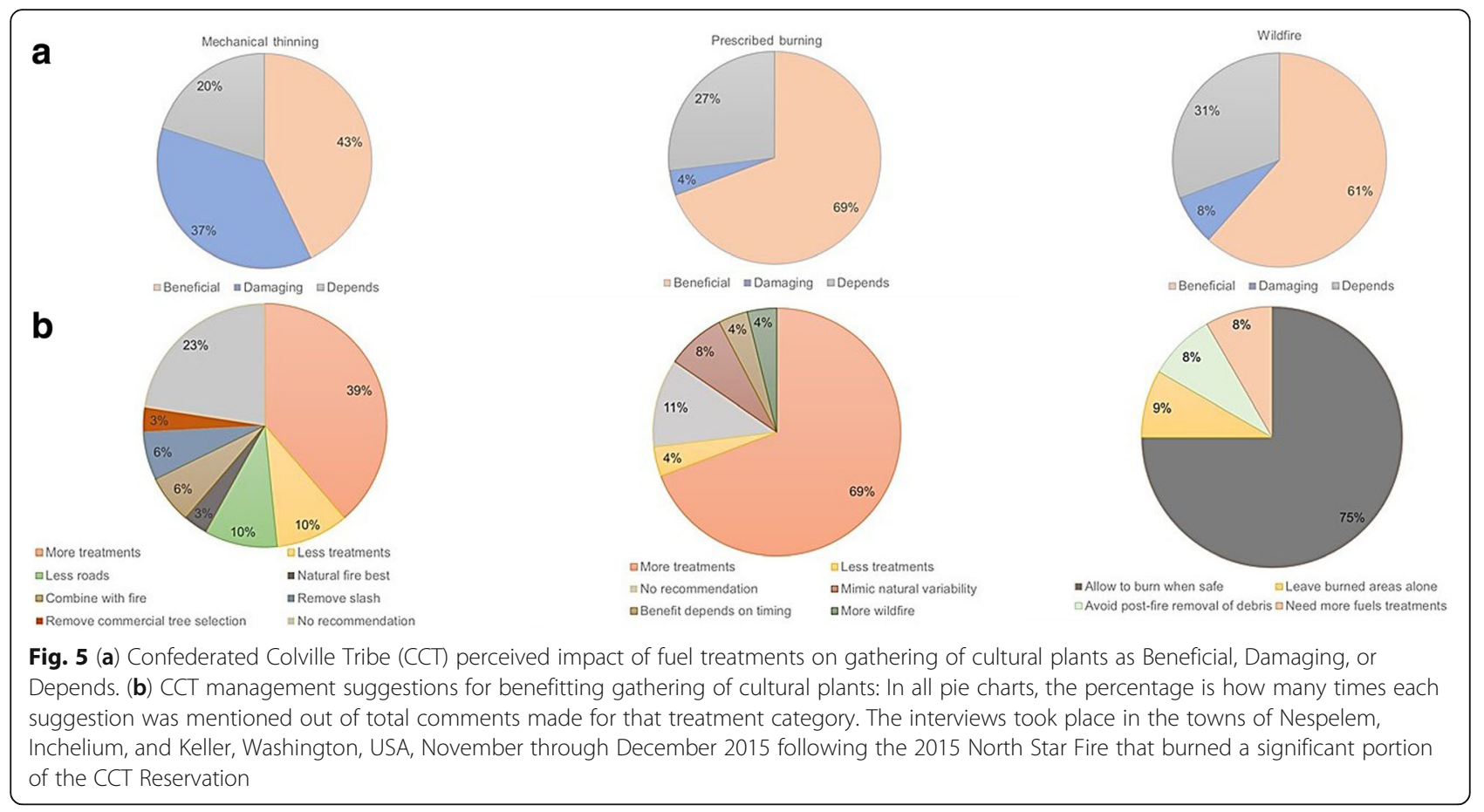

3. For wildfire, PGIS participants recommended allowing wildfire to burn when safe $(75 \%, n=9)$, implementing more fuel treatments for wildfire to be successful $(8 \%, n=1)$, avoiding post-fire removal of timber and debris $(8 \%, n=1)$, and leaving burned areas alone $(9 \%, n=1)$ (Fig. 5).
The maps produced from the PGIS mapping exercise showed where respondents felt fuels treatments would be most beneficial for cultural plants and where they should not be applied ( $n=37$; Fig. 6). The maps represented all responses from PGIS participants, with red being the greatest level of concern, measured as the
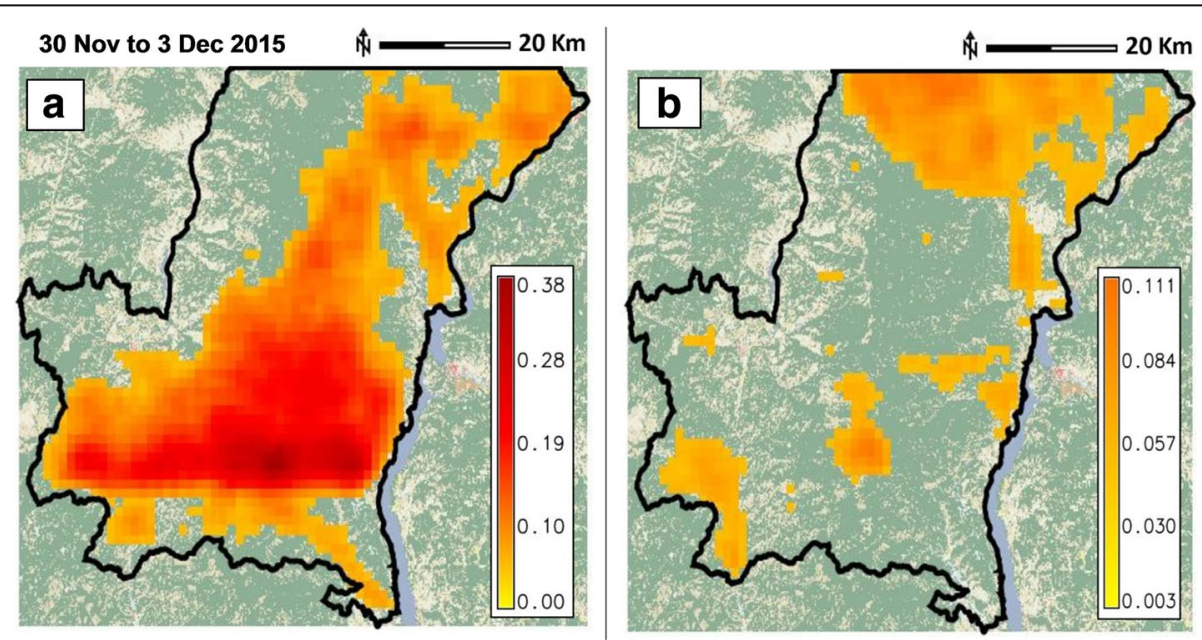

Fig. 6 Areas where PGIS participants $(n=37)$ felt that fuels treatments could be applied $(\mathbf{a})$, and where fuels treatments should be avoided $(\mathbf{b})$ on the Northeast Washington Collaborative Forest Landscape Restoration Area project area of the Colville National Forest, USA. The color scale on the lower right corner of the maps represents the proportion of PGIS participants that identified an area as benefiting from treatments or as a place where fuels treatments should be excluded for which 0 is none of participants and 1 is 100\% of participants. The interviews took place in the towns of Nespelem, Inchelium, and Keller, Washington, USA, November through December 2015 following the 2015 North Star Fire that burned a significant portion of the CCT Reservation 
count of respondents identifying the place, and yellow being of less concern. Areas on or close to the CCT border were high priority for fuel treatments for respondents. This is the area where treatments are currently being planned. Areas where participants felt that fuels treatments should be avoided were congregated around the Canadian-US border, around mountain tops, watersheds, prayer sites, and other sensitive locations that could be damaged more by fire suppression tactics or fuel treatments than by wildfire alone.

\section{Discussion}

Traditional knowledge about fuels and fire management

Our vegetation plots were located within areas where a majority of participants wanted to see more fuels treatments accomplished. This is likely influenced by the proximity of the plots to the Colville Reservation and in response to the recent North Star Fire that burned less than two months prior to when we conducted our PGIS exercise.

All fuels treatments were perceived by PGIS participants as having an impact on cultural plants and materials, whether damaging, beneficial, or a little bit of both, depending on various factors. Fuels treatments, such as understory thinning, can significantly reduce fuel loadings and can increase forest resilience to large wildfire events and enhance forest vegetation recovery (Hudak et al. 2011; Stevens-Rumann et al. 2013). Some PGIS participants felt that timely removal of slash from mechanical treatments is crucial for preventing harm to culturally significant plants as the result of treatment or in the event of a subsequent wildfire. Slash removal was also viewed as beneficial for improving access to foods, medicines, and firewood. Participants commented that, in thinned forest, it was easier to walk to and find cultural resources, some of which were of higher quality compared to those in untreated areas. Our fuel loading results supported this PGIS finding, as $1-h, 10-h$, and $100-\mathrm{h}$ timelag fuels were significantly reduced in the treated and un-treated plots burned by the North Star Fire. A reduction in 1-h and 10-h timelag fuels would likely reduce intensity and rate of spread when subsequent wildfires ignite (Stephens et al. 2009).

A majority of the PGIS comments were in favor of using wildland fire for resource benefit and prescribed fire over mechanical thinning alone. Almost as many participants perceived mechanical treatments as detrimental as those that perceived them as beneficial for cultural plants and practices. In contrast, there was a dominant perception of both prescribed fire and wildfire being beneficial for cultural plants and practices. Some participants explained that there were some traditional plants, such as huckleberry and western redcedar (Thuja plicata Donn ex D. Don), that are favored by fire but not by mechanical thinning. This cultural value of fire was supported by our finding that all burned plots (TB and $\mathrm{B}$ ), whether previously thinned and prescribed burned or not, showed significantly higher understory plant species diversity than in the treated plots that were not burned by wildfire at all $(\mathrm{T})$. Also, we found increased species richness within treated and burned (TB) plots, which is consistent with the comments of the PGIS participants that stated the importance of combining fuels treatments with fire to reduce the potential negative impacts of wildfires.

PGIS participants' comments regarding the value of natural variability of wildfire effects over those from prescribed fire following mechanical thinning are also supported by our results. Consistent with CCT tribal members' comments in the PGIS exercise, burn severity has been linked to understory plant species richness (Morgan et al. 2015), and wildfires that burn with a range of severity can increase the diversity of landscapes by offering islands of burned and unburned terrain for species with varying levels of fire adaptations (Schwilk et al. 2009; Burkle et al. 2015).

Most of the PGIS participants favored a combination of mechanical thinning and prescribed fire compared to mechanical thinning alone. Although there was overall agreement amongst PGIS participants about the benefits of mixed and low-severity wildfire, many voiced their concerns regarding the risk of a stand-replacing fire, such as what was seen within the interior of the 2015 North Star fire on the Okanogan Wenatchee National Forest and Colville Reservation. Commercial tree removal post wildfire, as well as use of logging equipment during and post wildfire, were of concern due to the increased risk that such equipment brings for introducing invasive plant species and damaging existing cultural plants. Similarly, Morgan et al. (2015) found that post-wildfire activities such as salvage logging in areas burned with high severity can reduce understory plant species richness, diversity, and cover.

Our results on plant diversity support both current science and the TK. Our results suggest that, if the maintenance of plant species diversity within forest ecosystems is a desired outcome, local managers need to strategically follow up mechanical thinning with some form of treatment, such as prescribed burning, particularly if treatments break up the homogeneity of the landscape (Keane et al. 2002; Schwilk et al. 2009).

\section{Traditional knowledge and cultural plants response to wildfires}

Tribal participants pointed out the important role that fire plays in rejuvenating and increasing the quality of the culturally important plants over time. Since our plot data were collected during the first growing period after 
the North Star Fire, our data may be showing an initial post-fire decrease in abundance, which may or may not be followed by an increase in abundance during the following growing seasons (Ahlgren 1974). With that in mind, plant response to wildfire within treated and untreated plots was consistent with many of the PGIS comments:

Huckleberry tends to sprout from rhizomes following fire (Flinn and Wein 1977), which is consistent with the relatively high cover of huckleberry that we observed in the first growing season post fire. Although huckleberry canopy cover did not significantly differ in the TB and B plots, the berries appeared larger and the foliage more dense within TB plots (M. Wynecoop, US Forest Service, Colville, Washington, USA, personal observation). An Interior Salish word for huckleberry translates to "sweet fruit," and has historically been a significant part of the diet and culture of the local tribes. Each band and family had their huckleberry patches that they returned to and managed regularly with fire to improve and maintain berry and bush quality and health (Turner et al. 1980). Some PGIS participants stated that the burning combined with opening up the forest canopy increased the size of the berries due to increased sunlight and nutrients within the berry patch, which was similarly reported by Gottesfeld (1994) and Boyd (1999). CCT PGIS participants indicated great concern for the impact that fuels reduction practices and wildfire might have on their huckleberry patches.

Serviceberry has been extremely important to all CCT bands, with the berries and wood used for food and medicinal purposes (Turner et al. 1980). According to Turner et al. (1980), the Lakes, Colville, and Sanpoil people recognized two main varieties of Saskatoon serviceberry, whereas the Northern Okanagan bands recognized eight varieties, each described by where it was typically found (i.e., sidehills, swamps, springs, basins, mountains, etc.), plant characteristics (i.e., bush height, leaf size, etc.), and quality of berry (i.e., berry size, amount of berries, size of seed, ability to dry, taste, etc.), medicine, or wood it provided. In British Columbia, Gottesfeld (1994) found that the local tribes commonly collected berries from Saskatoon serviceberry, but did not manage the bushes with fire like they did with their huckleberry bushes. Serviceberry is also highly valued for wildlife browse and cover. Our monitoring results may be useful when addressing CCT comments regarding the impact that fire has on gathering of foods and medicinal plants as well as on wildlife, and also whether or not thinning, prescribed fire, and wildfire will have a significant impact on hunting. Serviceberry tends to be extremely resilient to fire and it sprouts well following top-kill from fire (Fryer 1997), as we observed. Without change in browsing pressure, annual twig production tends to be greater following fire (Fryer 1997).

The mountain strawberry has many traditional food, medicinal, and other uses for the CCT, with the mountain variety found at the higher elevations being viewed as having higher quality berries (Turner et al. 1980). The runners were traditionally used to make twine, the leaves used for medicinal purposes, and the berries were sometimes mixed with other berries and foods to sweeten them (Turner et al. 1980). Strawberry survives fire well when the meristematic tissue is protected by a moist duff layer that limits duff consumption during fires (Powell 1994). Variability in duff consumption could explain why we observed highly variable cover of strawberry plants among and within $\mathrm{TB}$ and $\mathrm{B}$ plots. Although strawberry commonly increases following fire, abundance may decrease post fire and it can take up to 5 to 10 years for strawberry to regain pre-burn abundance (Munger 2006).

Kinnikinnick (also known as bearberry) is a culturally important species, both for traditional food and medicine (Hart 1976; Turner et al. 1980) and as important winter cover and browse for wildlife (Hill 1946; Keown 1977). There is a separate Interior Salish name used for the berries and the leaves. The different parts of the plant have both been used by the CCT and other tribes for food, smoking, and in concoctions used to treat various ailments (Turner et al. 1980). It is an especially important spring browse for bears when they come out of hibernation (Keown 1977). Thus, spring prescribed burning while some moisture remains in the soil could benefit the plants and wildlife, allowing the plants and wildlife time to recover before the next winter and stimulating spring plant growth. How well kinnikinnick is established prior to the fire burning and how severely the fire burns both influence post-fire abundance of kinnikinick (Fischer and Bradley 1987). The canopy cover of kinnikinick may decrease greatly where it is rooted in organic matter that is consumed in the fire. It is less likely to be harmed by wildfires when it is rooted in mineral soil (Crane 1991). Due to its moderate growth rate, kinnikinnick grows well in areas that burn with moderate- to low-severity fire, with fire return intervals long enough to allow root establishment deep within mineral soil (Crane 1991).

Heartleaf arnica has many medicinal uses for the Interior Salish groups of Washington and British Columbia (Turner et al. 1980; Turner 1988). An Interior Salish word for heartleaf arnica is translated as "facing each other" (Turner et al. 1980). It may rapidly re-grow through rapid flowering and heavy seed dispersal following fire and then decline in abundance within a few years post fire (Reed 1993a, 1993b), suggesting that frequent, low- to moderate-severity fires are beneficial to this species. 
Dwarf rose is culturally important to humans and wildlife, both medicinally and nutritionally as a source of vitamins, fiber, fat, and protein during the winter (Welch and Andrus 1977; Turner et al. 1980; Turner 1988). Dwarf rose has been shown to respond well to low- to medium-severity fire and it will resprout from rhizomes after shrubs are top-killed by fire (Reed 1993a, 1993b).

\section{Limitations}

We sampled vegetation response within only 30 plots, all in areas that burned with low severity, and on only one fire. Our 10 pre-wildfire plots were sampled in late August and early September 2015, during the end of the growing season, which could have influenced both species diversity and plant abundance. However, the six plant species that we focused on are all perennial species and were therefore easy to identify despite data collection late in the growing season. Our post-fire plots were only sampled in the first growing season post fire, in May 2016. Our paired plot design was useful in detecting differences despite our small sample size, although less so for the five plot pairs comparing burned only to plots burned and treated, than for the 10 pairs comparing treated and burned to treated only. Ongoing CFLRP monitoring of fuels treatment and fire impacts on tribal and non- tribal community values will help determine if our findings apply more broadly.

We primarily involved CCT elders and professionals that worked in natural resource management. While this might have increased the amount of detail provided in responses, a larger group of CCT participants could be more representative of the CCT.

Technological difficulties with the PGIS program hampered our efforts. Our PGIS questions were asking for people to share their values and concerns, which required a relationship of trust and transparency between all involved. Developing such trust can be difficult and takes time and required us to be educated on the history of the CCT and their treaty rights. We sought to be transparent and trustworthy. We sought to ensure that the participants, especially elders, knew that we were working on their time frame and were willing to assist them in any way possible to feel comfortable and respected. Changes have since been made to the PGIS program so that everyone, especially elders, are able to spend as much time as needed without the session "timing out" on them.

\section{Management and policy implications}

Understory vegetation diversity was greater one year after the North Star Fire in areas with and without prior broadcast burning and mechanical fuels treatments. The percent canopy cover of two of the six culturally important plants (Fragaria spp. and Arnica cordifolia) significantly increased one growing season post wildfire within treated plots and one (Arctostaphylos uva-ursi) significantly decreased in the treated plots post wildfire. Our participatory GIS exercise was effective for getting public input. By bridging the gap between traditional knowledge (TK) and western science, we addressed a common challenge for managers and scientists. Our approach is potentially useful to forest managers planning fuels treatments and managing wildfires while bridging cultures in ancestral tribal lands. The results from this project are currently being used by Colville National Forest fire and fuels managers in collaboration with the Confederated Colville Tribes for designing fuel treatments and for improving collaboration and trust between the Colville National Forest and local tribes.

\section{Conclusions}

For ancestral lands, sustainability involves hearing from the tribal communities that are intimately connected to the local landscape. Recently, Lake et al. (2017) stated that, "successful management of wildland fire and fuels requires collaborative partnerships that share traditional and Western fire knowledge through culturally sensitive consultation, coordination, and communication for building trust". Here, we have addressed that communication and cultural gap in management and science. We addressed the need for managers and scientists to take a multi-disciplinary and more holistic approach (Grimble and Wellard 1997; Berkes and Folke 1998) to understand and manage the cumulative effects of wildfire and common fuels treatments on understory plants of importance to tribal communities.

In April 2018, the Intertribal Timber Council released a fire report that emphasized the urgent need for changes to be made "in policies, programs, analytical tools, and procedures" to safeguard forest health and productivity, especially with regard to forestry and fire management within the lands held in trust for tribes (ITC 2018). Despite the need, few studies combine Western science and TK of local and indigenous communities, which is necessary for a comprehensive response to environmental and management impacts on traditional ways of life (EPA Tribal Science Council 2011). Globally and nationally, applications of this approach can strengthen communities and build relationships between agencies and communities (Bowman et al. 2009; Lynn et al. 2013). Focusing on food, medicine, and cultural values of our precious natural resources will serve to strengthen and return the human connections to our landscapes.

The results of this study have already informed fire and fuels management on the Colville National Forest. Our work has helped to facilitate discussions about incorporating the tribal PGIS feedback and TK 
into future CNF projects and has strengthened trust between the local tribes and the Colville National Forest. We demonstrated the value of PGIS and field data in monitoring the effectiveness of fuels treatments with regard to tribal social and cultural values. Our success in this project depended on our willingness to take the time needed to find the appropriate tribal contacts, to be respectful and considerate to participants, and to build trust with each and every tribal participant. The people involved in this study were passionate about helping the tribal people and that is what will ultimately ensure success of future projects that follow this approach. We hope that our social-ecological system approach will show the benefits of bringing back the tradition of sumés and honor that fire managers have traditionally held by returning the community feedback loop and traditional knowledge to natural resource management.

\section{Additional files}

\section{Additional file 1: Species list of the 58 understory plant species} observed within the 15 paired plots. Nomenclature follows the USDA Plants Database (USDA NRCS [US Department of Agriculture Natural Resources Conservation Service] 2017). (PDF 214 kb)

Additional file 2: Demographics of PGIS participants: tribal membership. Membership or quanta indicated includes: Confederated Colville Tribes (undefined); registered official bands on the Colville Indian Reservation (Colville, Sinixt [ArrowLakes], San Poil, Okanngan, Entiat, Chief Joseph Band of Nex Pierce, Wenachi, Moses-Columbia, Nespelem, Palus); and other tribes (Yakima, Coeur d'Alene, Umatilla, Salish-Kootenai). (PDF 116 kb)

Additional file 3: Demographics of PGIS participants: gender. Interviews took place in the towns of Nespelem, Inchelium, and Keller, Washington, USA, November through December 2015 following the 2015 North Star Fire that burned a significant portion of the CCT Reservation. (PDF $112 \mathrm{~kb}$ )

Additional file 4: Demographics of PGIS participants: age. Interviews took place in the towns of Nespelem, Inchelium, and Keller, Washington, USA, November through December 2015 following the 2015 North Star Fire that burned a significant portion of the CCT Reservation. (PDF $113 \mathrm{~kb}$ )

Additional file 5: Demographics of PGIS participants: profession. Titles indicated: business (agency administrator, office manager, realty specialist); forestry (forest manager [silviculturist], assistant forest manager, forester [silviculturist], forest development technician, fuels monitor, wildland fire fighter, assistant fire management officer, fuels planning assistant, timber sales officer); environment (environmental regulation, water administration); wildlife (natural resource officer, natural resource law enforcement, parks and recreation, wildlife biologist); heritage (elder, Integrated Resource Management plan, senior history and archaeology technician, traditional cultural plant technician); and other employment (transportation planner, homemaker, emergency medical technician, nurse). (PDF $112 \mathrm{~kb}$ )

Additional file 6: Number of Colville Reservation residents who took part in the consultation (30 November to 3 December 2015). Table A. Number of participants who did the map module, answered the questionnaire, or both. Table B. Number of participants who answered map question 1 ("Please indicate an area where fuels reduction treatments would provide the most benefit on the Colville National Forest"), map question 2 ("Please indicate an area where fuels reduction treatments should be avoided on the Colville National Forest"), or both The interviews took place in the towns of Nespelem, Inchelium, and Keller, Washington, USA, following the 2015 North Star Fire that burned a significant portion of the CCT Reservation. (PDF $150 \mathrm{~kb}$ )

\section{Acknowledgements}

We thank those that agreed to be part of the scoping group representing the Colville Tribal Elders, the Colville Indian Agency, and Bureau of Indian Affairs. C. Watt, Bureau of Indian Affairs/Colville Indian Agency, was our key contact and representative for the Confederated Colville Tribes. We thank T. Paveglio at the University of Idaho for his advice in design, implementation, and analysis. A special thanks to L. Wynecoop, who volunteered his time on the North Star Fire as fire lookout and crew member for the FFI rapid response data collection.

\section{Funding}

This project was funded by the Collaborative Forest Landscape Restoration Program, the USDA Forest Service Pacific Northwest Region's Ecology Program, the University of Idaho, and the International Association of Wildland Fire (scholarship to M.D. Wynecoop.). F. Sánchez-Trigueros and A. Watson were funded to participate in this research through a Joint Service Agreement between the Colville National Forest and the Rocky Mountain Research Station and their partners.

\section{Availability of data and materials}

The data that support the findings of this study are available from Colville Confederated Tribes, but restrictions apply to the availability of these data, which were authorized for this study, and so are not publicly available.

\section{Authors' contributions}

Study design (all authors), implementation and data analysis (MDW and FS-T), and writing (all authors). All authors read and approved the final manuscript.

\section{Ethics approval and consent to participate}

Prior to interviewing the PGIS participants, an application for a research permit was submitted and approved by the Confederated Tribes of the Colville Reservation. The project proposal was also presented to and approved by the Confederated Colville Tribal Natural Resource Committee. A project proposal was also submitted and approved by the Colville National Forest CFLRP Monitoring Committee and to the University of Idaho Human Research Protections approval committee.

\section{Consent for publication}

Not applicable.

\section{Competing interests}

The authors declare that they have no competing interests.

\section{Publisher's Note}

Springer Nature remains neutral with regard to jurisdictional claims in published maps and institutional affiliations.

\section{Author details}

${ }^{1}$ USDA Forest Service, Colville National Forest, 765 S. Main Street, Colville, Washington 99114, USA. ${ }^{2}$ Department of Forest, Rangeland, and Fire Sciences, University of Idaho, 975 Perimeter Drive MS 1133, Moscow, ID 83844, USA. ${ }^{3}$ University of Arizona, School of Geography and Development, 1064 E. Lowell Street, Tucson, AZ 85721, USA.

Received: 28 January 2019 Accepted: 30 January 2019

Published online: 03 June 2019

\section{References}

Agee, J.K., and C.N. Skinner. 2005. Basic principles of forest fuel reduction treatments. Forest Ecology and Management 211(1-2): 83-96. https://doi.org/ 10.1016/j.foreco.2005.01.034

Ahlgren, C.E. 1974. Effects of fires on temperate forests: North Central United States. Pages 195-223 in: T.T. Kozlowski and C.E. Ahlgren, editors. Fire and ecosystems. Academic Press, New York, New York, USA. https://doi.org/10.1016/B978-0-12424255-5.50011-0

Berkes, F., J. Colding, and C. Folke. 2000. Rediscovery of traditional ecological knowledge as adaptive management. Ecological Applications 10(5): 12511262. https://doi.org/10.1890/1051-0761(2000)010[1251:ROTEKA]2.0.CO;2.

Berkes, F., and C. Folke. 1998. Linking social and ecological systems for resilience and sustainability. Pages 1-25 in: F. Berkes, C. Folke, and J. Colding, editors. Linking social and ecological systems: management practices and social mechanisms for building resilience. Cambridge University, New York, New York, USA. 
Bowman, D.M., J.K. Balch, P. Artaxo, W.J. Bond, J.M. Carlson, M.A. Cochrane, C.M. D'Antonio, R.S. DeFries, J.C. Doyle, S.P. Harrison, and F. Johnston. 2009. Fire in the Earth system. Science 324: 481-484. https://doi.org/10.1126/science.1163886.

Boyatzis, R. 1998. Transforming qualitative information: thematic analysis and code development. Sage Publications, Thousand Oaks, California, USA.

Boyd, R., editor. 1999. Indians, fire, and the land in the Pacific Northwest. Corvallis: Oregon State University Press, Corvallis, Oregon, USA.

Burkle, L., J. Myers, and R. Belote. 2015. Wildfire disturbance and productivity as drivers of plant species diversity across spatial scales. Ecosphere 6(10): 1-14. https://doi.org/10.1890/ES15-00438.1.

Carrol, M.S., P.J. Cohn, T.B. Paveglio, D.R. Drader, and P.J. Jakes. 2010. Fire burners to firefighters: the Nez Perce and fire. Journal of Forestry 108(2): 71-76.

CCT [Confederated Colville Tribes] 2015. Integrated Resource Management Plan. <https://static1.squarespace.com/static/56a24f7f841aba12ab7ecfa9/t/ 587559bdf7e0ab87833fab9b/1484085737362/IRMP+Public+Review.pdf>. Accessed 17 Apr 2017.

CCT [Confederated Colville Tribes]. 2017. The Confederated Tribes of the Colville Reservation is a sovereign nation. <https://www.cct-hsy.com/facts/>. Accessed 20 Mar 2017.

Christiansen, A. 2015. Social science research on indigenous wildfire management in the 21st century and future research needs. International Journal of Wildland Fire 24(2): 190-200.

Cohen, L., L. Manion, and K. Morrison. 2013. Research methods in education. Routledge, New York, New York, USA.

Crane, M.F. 1991. Arctostaphylos uva-ursi. Fire Effects Information System. USDA Forest Service. <http://www.fs.fed.us/database/feis/plants/shrub/arcuva/all.html>. Accessed 1 Mar 2017.

Curtis, L.S. 2010. Flathead watershed sourcebook: A guide to an extraordinary place. Thomas Printing, Kalispell, Montana, USA.

DeCuir-Gunby, J.T., P.L. Marshall, and A.W. McCulloch. 2011. Developing and using a codebook for the analysis of interview data: an example from a professional development research project. Field Methods 23(2): 136-155. https://doi.org/10.1177/1525822X10388468.

DellaSala, D., A. Martin, R. Spivak, T. Schulke, B. Bird, M. Criley, C. van Daalen, J. Kreilick, R. Brown, and G. Aplet. 2003. A citizen's call for ecological forest restoration: forest restoration principles and criteria. Ecological Restoration 21(1): 14-23. https://doi.org/10.3368/er.21.1.14.

EPA Tribal Science Council. 2011. Integration of Traditional Ecological Knowledge (TEK) in environmental science, policy, and decision-making. <https://archive.epa. gov/region9/tribal/web/pdf/tribal-ecological-knowledge-env-sci-policy-dm.pdf>. Accessed 30 May 2015.

Esri. 2014. ArcMap 10.2. Redlands: Esri, Redlands, California, USA.

Fischer, W.C., and A.F. Bradley. 1987. Fire ecology of western Montana forest habitat types. USDA Forest Service General Technical Report INT-223, Ogden Utah, USA.

Flinn, M.A., and R.W. Wein. 1977. Depth of underground plant organs and theoretical survival during fire. Canadian Journal of Botany 55(19): 2550-2554. https://doi.org/10.1139/b77-291.

Fryer, J.L. 1997. Amelanchier alnifolia. Fire Effects Information System. USDA Forest Service. <http://www.fs.fed.us/database/feis/plants/shrub/amealn/all.html>. Accessed 18 Sep 2017.

Fulé, P.Z., J.E. Crouse, J.P. Roccaforte, and E.L. Kalies. 2012. Do thinning and/or burning treatments in western USA ponderosa or Jeffrey pine-dominated forests help restore natural fire behavior? Forest Ecology and Management 269: 68-81.

Gottesfeld, L.M.J. 1994. Aboriginal burning for vegetation management in Northwest British Columbia. Human Ecology 22(2): 171-188. https://doi.org/ 10.1007/BF02169038.

Green, D., and G. Raygorodetsky. 2010. Indigenous knowledge of a changing climate. Climatic Change 100(2): 239-242. https://doi.org/10.1007/s10584-010-9804-y.

Grimble, R., and K. Wellard. 1997. Stakeholder methodologies in natural resource management: a review of principles, contexts, experiences and opportunities. Agricultural Systems 55(2): 173-193. https://doi.org/10.1016/S0308-521X(97)00006-1.

Gundale, M.J., T.H. DeLuca, C.H. Fiedler, P.W. Ramsey, M.G. Harrington, and J.E. Gannon. 2005. Restoration treatments in a Montana ponderosa pine forest: Effects on soil physical, chemical and biological properties. Forest Ecology and Management 213(1): 25-38. https://doi.org/10.1016/j.foreco.2005.03.015.

Gunderson, K., S. Carver, and B.H. Davis. 2011. Human relationships to fire prone ecosystems: mapping values at risk on contested landscapes. Pages 134-139 in: A. Watson, J. Murrieta-Saldivar, and B. McBride, compilers. Science and stewardship to protect and sustain wilderness values: Ninth World Wilderness Congress symposium. USDA Forest Service Proceedings RMRS-P64, Rocky Mountain Research Station, Fort Collins, Colorado, USA
Hart, J. 1976. Montana — native plants and early peoples. Montana Historical Society Helena, Montana, USA.

Hessburg, P.F., D.J. Churchill, A.J. Larson, R.D. Haugo, C. Miller, T.A. Spies, M.P. North, N.A. Povak, R.T. Belote, P.H. Singleton, and W.L. Gaines. 2015. Restoring fire-prone inland Pacific landscapes: seven core principles. Landscape Ecology 30(10): 1805-1835. https://doi.org/10.1007/s10980-015-0218-0.

Hessburg, P.F., T.A. Spies, D.A. Perry, C.N. Skinner, A.H. Taylor, P.M. Brown, S.L. Stephens, A.J. Larson, D.J. Churchill, N.A. Povak, and P.H. Singleton. 2016. Tamm review: management of mixed-severity fire regime forests in Oregon, Washington, and northern California. Forest Ecology and Management 366: 221-250.

Hill, R.R. 1946. Palatability ratings of Black Hills plants for white-tailed deer. Journal of Wildlife Management 10(1): 47-54. https://doi.org/10.2307/3795814.

Hudak, A.T., I. Rickert, P. Morgan, E. Strand, S.A. Lewis, P. Robichaud, C. Hoffman, and Z.A. Holden. 2011. Review of fuel treatment effectiveness in forests and rangelands and a case study from the 2007 megafires in Central Idaho USA. USDA Forest Service General Technical Report RMRS-GTR-252, Rocky Mountain Research Station Fort Collins, Colorado, USA.

Ihaka, R., and R. Gentleman. 1996. R: a language for data analysis and graphics. Journal of Computational and Graphical Statistics 5(3): 299-314.

Kalies, E.L., and L.L. Yocom Kent. 2016. Tamm review: are fuel treatments effective at achieving ecological and social objectives? A systematic review. Forest Ecology and Management 375: 84-95. https://doi.org/10.1016/j.foreco.2016.05.021.

Kane, J.M., M.J. Varner, E.E. Knapp, and R.F. Powers. 2010. Understory vegetation response to mechanical mastication and other fuels treatments in a ponderosa pine forest. Applied Vegetation Science 13(2): 207-220. https://doi. org/10.1111/j.1654-109X.2009.01062.x.

Keane, R.E., K.C. Ryan, T.T. Veblen, C.D. Allen, J.A. Logan, and B. Hawkes. 2002. The cascading effects of fire exclusion in Rocky Mountain ecosystems. USDA Forest Service General Technical Report RMRS-GTR-91. Rocky Mountain Research Station Fort Collins, Colorado, USA

Keown, L.D. 1977. Interim report: Black Tail Hills prescribed fire project: implementation and results. USDA Forest Service, Lewis and Clark National Forest, Great Falls, Montana, USA.

Kershaw, L.J. 2000. Edible and medicinal plants of the Rockies. Lone Pine Publishing, Edmonton, Alberta, Canada.

Kimmerer, R.W., and F.K. Lake. 2001. The role of indigenous burning in land management. Journal of Forestry 99(11): 36-41.

Lake, F.K., V. Wright, P. Morgan, M. McFadzen, D. McWethy, and C.S. Stevens-Rumann. 2017. Returning fire to the land: celebrating traditional knowledge and fire. Journal of Forestry 115(5): 343-353. https://doi.org/10.5849/jof.2016-043R2.

Lentile, L.B., P. Morgan, C. Hardy, A. Hudak, R. Means, R. Ottmar, P. Robichaud, E.K. Sutherland, J. Szymoniak, F. Way, and J. Fites-Kaufman. 2007. Value and challenges of conducting rapid response research on wildland fires. USDA Forest Service General Technical Report RMRS-GTR-193, Rocky Mountain Research Station, Fort Collins, Colorado, USA.

Lutes, D.C., R.E. Keane, J.F. Caratti, C.H. Key, N.C. Benson, S. Sutherland, and L.J. Gangi. 2006. FIREMON: Fire effects monitoring and inventory system. In USDA Forest Service general technical report RMRS-GTR-164-CD. Fort Collins: Rocky Mountain Research Station.

Lynn, K., J. Daigle, J. Hoffman, F. Lake, N. Michelle, D. Ranco, C. Viles, G. Voggesser, and P. Williams. 2013. The impacts of climate change on tribal traditional foods. Climatic Change 120(3): 545-556. https://doi.org/ 10.1007/s10584-013-0736-1.

McBride, B.B., F. Sanchez-Trigueros, S.J. Carver, A.E. Watson, L.M. Stumpff, R. Matt, and W.T. Borrie. 2017. Participatory geographic information systems as an organizational platform for the integration of traditional and scientific knowledge in contemporary fire and fuels management. Journal of Forestry 115(1): 43-50. https://doi.org/10.5849/jof.14-147.

McCune, B., J.B. Grace, and D.L. Urban. 2002. Analysis of ecological communities. MjM Software Design Gleneden Beach, Oregon, USA.

Metlen, K.L., C.E. Fiedler, and A. Youngblood. 2004. Understory response to fuel reduction treatments in the Blue Mountains of northeastern Oregon. Northwest Science 78(3): 175-185.

Morgan, P., M. Moy, C. Droske, L. Lentile, S. Lewis, P. Robichaud, A. Hudak, and C. Williams. 2015. Vegetation response to burn severity, seeding and salvage logging. Fire Ecology 11(2): 31-58. https://doi.org/10.4996/fireecology.1102031.

Munger, G.T. 2006. Fragaria vesca. Fire Effects Information System. USDA Forest Service. https://www.fs.fed.us/database/feis/plants/forb/fraves/all.html. Accessed 1 Mar 2017

Powell, D.C. 1994. Effects of the 1980s western spruce budworm outbreak on the Malheur National Forest in northeastern Oregon. USDA Forest Service, 
Technical Publication R6-FI\&D-TP-12-94. Pacific Northwest Region, Natural Resources Staff, Forest Insects and Diseases Group, Portland, Oregon, USA.

Reed, W.R. 1993a. Arnica cordifolia. Fire Effects Information System. USDA Forest Service. https://www.fs.fed.us/database/feis/plants/forb/arncor/all.html. Accessed 18 Sep 2017.

Reed, W.R. 1993b. Rosa gymnocarpa. Fire Effects Information System. USDA Forest Service. https://www.fs.fed.us/database/feis/plants/shrub/rosgym/all.html. Accessed 18 Sep 2017.

Schwilk, D.W., J.E. Keeley, E.E. Knapp, J. Mclver, J.D. Bailey, C.J. Fettig, C.E. Fiedler, R. J. Harrod, J.J. Moghaddas, K.W. Outcalt, and C.N. Skinner. 2009. The national Fire and Fire surrogate study: effects of fuel reduction methods on forest vegetation structure and fuels. Ecological Applications 19(2): 285304. https://doi.org/10.1890/07-1747.1

Stephens, S.L., J.J. Moghaddas, C. Edminster, C.E. Fiedler, S. Haase, M. Harrington, J.E. Keeley, E.E. Knapp, J.D. Mclver, K. Metlen, and C.N. Skinner. 2009. Fire treatment effects on vegetation structure, fuels, and potential fire severity in western US forests. Ecological Applications 19(2): 305-320. https://doi.org/10. 1890/07-1755.1.

Stevens-Rumann, C., K. Shive, P. Fulé, and C. Sieg. 2013. Pre-wildfire fuel reduction treatments result in more resilient forest structure a decade after wildfire. International Journal of Wildland Fire 22(8): 1108-1117. https://doi.org/10. 1071/WF12216.

Stine, P., P. Hessburg, T. Spies, M. Kramer, C.J. Fettig, A. Hansen, J. Lehmkuhl, K. O'Hara, K. Polivka, P. Singleton, and S. Charnley. 2014. The ecology and management of moist mixed-conifer forests in eastern Oregon and Washington: a synthesis of the relevant biophysical science and implications for future land management. USDA Forest Service General Technical Report PNW-GTR-897. Pacific Northwest Research Station, Portland, Oregon, USA.

STOI [Spokane Tribe of Indians]. 2012. Sustainable community master plan: the STOI 2012 comprehensive plan. <http://www.spokanetribe.com/userfiles/file/ SCMP\%20Draft\%209_26_2012.pdf>. Accessed 18 Sep 2018.

Swanson, S., and W. Gilgert. 2009. Fuels management at the landscape scale. Rangelands 31(3): 25-29. https://doi.org/10.2111/1551-501X-31.3.25.

Turner, N.J. 1988. The importance of a rose: Evaluating the cultural significance of plants in Thompson and Lillooet Interior Salish. American Anthropologist 90(2): 272-290. https://doi.org/10.1525/aa.1988.90.2.02a00020.

Turner, N.J., R. Bouchard, and D.I.D. Kennedy. 1980. Ethnobotany of the OkanaganColville Indians of British Columbia and Washington. Occasional paper of the British Columbia Provincial Museum no. 21, British Columbia Provincial MuseumVictoria, British Columbia, Canada.

USDA Forest Service. 2014. The National Strategy. Available online at https:// www.forestsandrangelands.gov/strategy/documents/strategy/ CSPhaselllNationalStrategyApr2014.pdf. Last accessed 23 Apr 2017.

USDA NRCS [US Department of Agriculture Natural Resources Conservation Service]. 2017. PLANTS Database. <https://plants.usda.gov/java/>. Accessed 18 Sep 2017.

Viera, A.J., and J.M. Garrett. 2005. Understanding interobserver agreement: the kappa statistic. Family Medicine 37 (5): 360-363.

Voggesser, G., K. Lynn, J. Daigle, F.K. Lake, and D. Ranco. 2013. Cultural impacts to tribes from climate change influences on forests. Climatic Change 120(3): 615-626. https://doi.org/10.1007/s10584-013-0733-4.

Welch, B.L., and D. Andrus. 1977. Rose hips-a possible high-energy food for wintering mule deer? USDA Forest Service Research Note INT-221, Intermountain Range and Forest Experiment Station, Ogden, Utah, USA.

Willms, J., A. Bartuszevige, D.W. Schwilk, and P.L. Kennedy. 2017. The effects of thinning and burning on understory vegetation in North America: a metaanalysis. Forest Ecology and Management 392: 184-194. https://doi.org/10. 1016/j.foreco.2017.03.010.

Wynecoop, M.D. 2017. Getting back to fire sumési: incorporating traditional knowledge into fuels reduction treatments. Thesis, University of Idaho Moscow, USA.

\section{Submit your manuscript to a SpringerOpen ${ }^{\circ}$ journal and benefit from:}

- Convenient online submission

- Rigorous peer review

- Open access: articles freely available online

- High visibility within the field

- Retaining the copyright to your article

Submit your next manuscript at $\boldsymbol{\nabla}$ springeropen.com 